\title{
PENERAPAN MODEL INDUKTIF KATA BERGAMBAR DALAM MENINGKATKAN KETERAMPILAN MENULIS BAHASA INDONESIA DI MADRASAH IBTIDAIYAH
}

\author{
Kurniadi Abdurrahim ${ }^{1}$ \\ ${ }^{\prime}$ MIN 2, Kota Bandung, Indonesia \\ kurniadiabdurrahim@gmai.com \\ Naskah diterima: 1 Desember, 2018, direvisi: 29 Januari, 2019, diterbitkan: 31 Maret, 2019
}

\begin{abstract}
This research was conducted to know Indonesia language writing skills of students before and after using the inductive model picture and words to find out its application in class II MI Nurul Huda Bandung. This research uses Research Action class that have been implemented over the last two cycles. Based on the results of the data processing, the average value obtained the writing skills of students before using inductive model illustrated 60 words (30\%). Application of inductive model illustrated words on cycle I obtained average value of teacher activity $80.75 \%$ and students of $68.75 \%$ and cycle II obtained average value of teacher activity amounted to $96.15 \%$ and $93.75 \%$ students. Writing skills of the students after using inductive model illustrated words on cycle I gained an average rating of 74,5 (78\%) and in cycle II obtained an average score of 81.6 (100\%). This proves that the word inductive model illustrated is able to improve the writing skills of students in the class II MI Nurul Huda Bandung.
\end{abstract}

Keywords: Model, Skills, Writing

\begin{abstract}
ABSTRAK
Penelitian ini dilakukan untuk mengetahui keterampilan menulis bahasa Indonesia siswa sebelum dan sesudah menggunakan model induktif kata bergambar serta untuk mengetahui penerapannya di kelas II MI Nurul Huda Kota Bandung. Penelitian ini menggunakan Penelitian Tindakan Kelas yang telah dilaksanakan selama dua siklus. Berdasarkan hasil pengolahan data, diperoleh nilai rata-rata keterampilan menulis siswa sebelum menggunakan model induktif kata bergambar 60 (30\%). Penerapan model induktif kata bergambar pada siklus I diperoleh nilai rata-rata aktivitas guru sebesar $80,75 \%$ dan siswa sebesar $68,75 \%$ dan pada siklus II diperoleh nilai rata-rata aktivitas guru sebesar 96,15\% dan siswa 93,75\%. Keterampilan menulis siswa sesudah menggunakan model induktif kata bergambar pada siklus I diperoleh nilai rata-rata sebesar 74,5(78\%) dan pada siklus II diperoleh nilai rata-rata 81,6 (100\%). Hal ini membuktikan bahwa model induktif kata bergambar mampu meningkatkan keterampilan menulis siswa di kelas II MI Nurul Huda Kota Bandung.
\end{abstract}

Kata Kunci: Model, keterampilan, menulis

\section{PENDAHULUAN}

Dalam Undang-Undang No. 20 Tahun 2003 Tentang Sistem pendidikan Nasional dijelaskan bahwa "Pendidikan adalah usaha sadar dan terencana untuk mewujudkan suasana belajar dan proses pembelajaran agar peserta didik secara aktif mengembangkan potensi dirinya untuk memiliki kekuatan spritual keagamaan, pengendalian diri, kepribadian,kecerdasan, akhlak mulia, serta keterampilan yang diperlukan dirinya,masyarakat,bangsa dan negara" (Anwar, 2017).

Untuk mencapai tujuan pendidikan nasional yang telah tercantum dalam undangundang, seorang guru harus membuat perencanaan pembelajaran yang baik untuk meningkatkan kesempatan belajar bagi siswanya. Hal tersebut menuntut adanya perubahan dalam mengelola kelas, penggunaan metode pembelajaran, strategi belajar, maupun cara 
seseorang guru dalam mengelola proses belajar mengajar. Salah satu cara untuk mencapai tujuan pendidikan nasional adalah dengan penerapan model pembelajaran. Model pembelajaran adalah suatu perencanaan yang digunakan sebagai pedoman dalam melaksanakan proses pembelajaran di kelas dan untuk menentukan material maupun perangkat pembelajaran (Suhada, 2016). Pembelajaran adalah seperangkat kondisi yang diciptakan dan dirancang untuk mendorong serta mendukung proses belajar siswa (Jamaludin, 2015). Dalam proses pembelajaran,seringkali siswa kurang termotivasi untuk mengikuti pembelajaran dikarenakan metode, media, model, pembelajaran yang kurang menarik.

Menurut Bruce, Marsha dan Emily (Ulya, 2013) model induktif kata bergambar adalah salah satu model pembelajaran yang berurusan dengan upaya pengembangan kosa kata, dan bagaimana memindah kata - kata tersebut kedalam memori jangka panjang. Model induktif kata bergambar melakukan pendekatan langsung pada perkembangan kosakata. Anak diminta membaca dengan cara mengeja pada kosakata yang ada di gambar, kemudian anak menulisnya. Dalam model ini akan melatih anak dalam membaca dan mengembangakan kosakata, model ini adalah penggunakan gambar sebagai stimulus bagi pengalaman berbahasa maka aktivitas - aktivitas di ruang kelas perlu dikembangkan untuk diterapkan dalam seni - seni berbahasa, khususnya untuk melatih para pembaca pemula dalam membaca dan menulis dengan baik. Dari penjelasan di atas, dapat disimpulkan bahwa model induktif kata bergambar melakukan pendekatan langsung kepada peserta didik, dalam model ini akan melatih anak dalam membaca dan mengembangkan kosakata, model ini menggunakan gambar sebagai setimulus, menggunakan gambar yang ditampilkan berupa animasi melalui penanyangan laptop. Bagaimana siswa mampu membaca dan menulis (terutama dalam hal perkembangan bahasa mereka, proses belajar mengajar mereka dalam membaca dan menulis).

Bahasa Indonesia memiliki peran sentral dalam perkembangan intelektual, social, dan emosional, siswa Madrasah Ibtidaiyah bahasa merupakan penunjang keberhasilan siswa dalam mempelajari semua mata pelajaran membantu siswa dalam mengenal dirinya, budayanya, dan budaya orang lain, menggemukakan gagasan dan perasaan, berpasitipasi dalam masyarakat yang menggemukakan bahasa tersebut, dan menemukan serta menggunakan kemampuan analitis dan imaginative yang ada dalam dirinya (Depdiknas, 2008). Pembelajaran bahasa Indonesia terutama di sekolah dasar tidak akan terlepas dari empat keterampilan berbahasa, yaitu menyimak, berbicara, membaca, dan menulis. Perkembangan bahasa anak, terjadi sering dengan perkembangan intelektual anak, pada saat anak memasuki usia sekolah dasar, anak akan terkordinasi untuk mempelajari bahasa tulis, pada masa ini, anak akan diuntut untuk lebih berfikir lebih dalam lagi agar kemampuan berbahasa dan mengalami perkembangan.menurut (Susanto, 2013:244).

Pembelajaran dapat diartikan sebagai suatu sistem atau proses mengajarkan siswa yang telah direncanakan, dilaksanakan dan dievaluasi secara sistematis agar peserta didik mencapai tujuan pembelajran secara baik dan benar. Pembelajaran juga dapat diartikan sebagai upaya yang dilakukan oleh guru agar terjadi proses belajar pada diri peserta didik, didalam pembelajaran ada kegiatan memilih, menetapkan dan mengembangakan metode untuk mencapai hasil pembelajaran yang diinginkan (Sobry, 2008).

Tujuan dari pembelajaran bahasa Indonesia yaitu Bahasa memiliki peran dalam perkembangan intelektual, sosial, dan emosional peserta didik dan merupakan keberhasilan dalam pelajaran semua bidang studi, pembelajaran bahasa diharapkan membantu pesera didik agar biasa mengenal dirinya, budayanya, dan budaya orang lain, pembelajaran bahasa Indonesia diarahkan untuk meningkat kemampuan peserta didik untuk berkomunikasi 
dalam bahas Indonesia dengan baik dan benar, baik secara lisan maupun tulisan, serta menimbulkan karya kesastraan manusia Indonesia (Saefuddin).

Berdasarkan hasil observasi di MI Nurul Huda Kota Bandung, ditemukan permasalahan dalam proses pembelajaran, khususnya di kelas II pada mata pelajaran bahasa Indonesia, terdapat sebagian besar siswa kurang terampil dalam menulis bahasa Indonesia. Sehingga berdampak pada proses pembelajaran pada mata pelajaran yang lainnya.

\section{METODOLOGI}

Penelitian ini menggunakan metode penelitian tindakan kelas. Peneliti bertindak langsung sebagai guru yang mengajar di kelas bertujuan untuk meningkatkan kualitas pembelajaran dan keterampilan menulis siswa. Penelitian ini dilakukan sebanyak dua siklus dan setiap siklus terdiri atas dua tindakan. Setiap tindakan terdiri dari empat langkah yaitu perencanaan, pelaksanaan, observasi dan refleksi. Penelitian ini dilakasanakan pada bulan April 2018, di Madrasah Ibtidaiyah Nurul Huda Kota Bandung. Subjek utama penelitian ini adalah siswa kelas II berjumlah 2, terdiri dari 9 orang laki-laki dan 14 orang perempuan. Pendekatan kuantitatif pada penelitian ini terletak pada teknik pengumpulan data berupa numerik yang diperoleh dari hasil penilaian produk yang diberikan kepada siswa setiap akhir siklus dan hasil skor yang didapat dari skor yang didapat pada lembar observasi aktivitas guru dan aktivitas siswa yang dilakukan pada setiap tindakan. Sedangkan pendekatan kualitatif pada penelitian ini terletak pada pengumpulan data yang bersifat informasi teks yang didasarkan pada situasi pembelajaran yang. Pembelajaran yang berlangsung diobservasi oleh observer dengan merujuk pada lembar observasi aktivitas guru dan lembar aktivitas siswa yang dilakukan pada setiap. Jenis data yang dikumpulkan dalam penelitian ini adalah data kualitatif dan kuantitatif. Data kualitatif merupakan data yang diperoleh dari deskripsi lembar observasi yang digunakan untuk memberikan gambaran proses pembelajaran bahasa Indonesia melalui metode induktif kata bergambar kelas II MI Nurul Huda yang meliputi aktvitas guru dan siswa. Sedangkan data kuantitatif adalah data yang berupa angka-angka dan bertujuan untuk memperoleh informasi mengenai data tentang penerapan metode induktif kata bergambar pada pembelajaran Bahasa Indonesia yaitu melalui hasil penilaian produk pada setiap akhir siklus dan hasil skor dari lembar observasi aktivitas guru dan aktivitas siswa. Sumber data pada penelitian ini terbagi menjadi dua yaitu sumber data primer dan sumber data sekunder.

Teknik pengumpulan data pada penelitian yaitu dengan penilaian produk dan observasi.

\section{Analisis Data Hasil Tes}

Tabel 1. Rubrik Penilaian Produk Keterampilan Menulis

\begin{tabular}{|c|c|c|c|c|c|}
\hline \multirow[t]{2}{*}{ No. } & \multirow{2}{*}{$\begin{array}{c}\text { Aspek Yang } \\
\text { Dinilai }\end{array}$} & \multicolumn{4}{|c|}{ Kriteria } \\
\hline & & 4 & 3 & 2 & 1 \\
\hline 1. & $\begin{array}{l}\text { Kerapihan } \\
\text { Tulisan }\end{array}$ & $\begin{array}{l}\text { Siswa } \\
\text { mampu } \\
\text { menulis } \\
\text { sangat } \\
\text { rapih } \\
\text {,mudah di } \\
\text { baca dan } \\
\text { tida adak } \\
\text { ada coretan }\end{array}$ & $\begin{array}{l}\text { Siswa } \\
\text { mampu } \\
\text { menulis } \\
\text { dengan rapih } \\
\text {,mudah di } \\
\text { baca dan } \\
\text { terdapat } \\
\text { sedikit } \\
\text { coretan. }\end{array}$ & $\begin{array}{l}\text { Siswa } \\
\text { mampu } \\
\text { menulis } \\
\text { cukup } \\
\text { rapih } \\
\text {,cukup } \\
\text { terbaca } \\
\text { dan ada } \\
\text { sedikit }\end{array}$ & $\begin{array}{l}\text { Siswa } \\
\text { tidak } \\
\text { mampu } \\
\text { menulis } \\
\text { dengan } \\
\text { rapih }\end{array}$ \\
\hline
\end{tabular}




\begin{tabular}{|c|c|c|c|c|c|}
\hline & & . & & coretan. & \\
\hline 2. & $\begin{array}{l}\text { Kelengkapan } \\
\text { kata }\end{array}$ & $\begin{array}{l}\text { Penulisan } \\
\text { kalimat } \\
\text { sudah jelas }\end{array}$ & $\begin{array}{l}\text { Penulisan } \\
\text { kalimat } \\
\text { belum } \\
\text { lengkap } \\
\text { yaitu } \\
\text { tertinggal I - } \\
2 \text { kata. }\end{array}$ & $\begin{array}{l}\text { Penulisan } \\
\text { kalimat } \\
\text { belum } \\
\text { lengkap } \\
\text { yaitu } \\
\text { tertinggal } \\
\text { 3-5 kata. }\end{array}$ & $\begin{array}{l}\text { Penulisan } \\
\text { kalimat } \\
\text { sudah } \\
\text { jelas }\end{array}$ \\
\hline 3. & $\begin{array}{l}\text { Susunan kata } \\
\text { dalam kalimat }\end{array}$ & $\begin{array}{l}\text { Susunan } \\
\text { kata dalam } \\
\text { kalimat } \\
\text { tidak benar }\end{array}$ & $\begin{array}{l}\text { Susuanan } \\
\text { kata dalam } \\
\text { kalimat } \\
\text { sudah benar } \\
\text { tetapi hanya } \\
\text { seperempat } \\
\text { bagian }\end{array}$ & $\begin{array}{l}\text { Susuanan } \\
\text { kata dalam } \\
\text { kalimat } \\
\text { sudah } \\
\text { benar } \\
\text { tetapi } \\
\text { hanya } \\
\text { setengah } \\
\text { bagian }\end{array}$ & $\begin{array}{l}\text { Susunan } \\
\text { kata } \\
\text { dalam } \\
\text { kalimat } \\
\text { sudah } \\
\text { benar }\end{array}$ \\
\hline
\end{tabular}

a. Ketuntasan Individu

Pada penelitian ini, penelitian memberikan rentang skor 1-4. Perhitungan skor maksimal 12 dengan rumus:

$$
\frac{\text { Jumlah skor yang diperoleh }}{\text { Skor maksimal }} \times 100
$$

Tabel 2. Skoring Rubrik Penilaian Keterampilan Menulis

\begin{tabular}{|c|c|c|c|c|c|c|c|c|c|c|c|c|c|c|c|}
\hline \multirow{3}{*}{$\mathrm{NO}$} & \multirow{3}{*}{ Nama Siswa } & \multicolumn{12}{|c|}{ Aspek yang Diamati } & \multirow{3}{*}{ Skor } & \multirow{3}{*}{ Nilai } \\
\hline & & \multicolumn{4}{|c|}{$\begin{array}{l}\text { Keterampilan } \\
\text { Tulisan }\end{array}$} & \multicolumn{4}{|c|}{$\begin{array}{c}\text { Kelengkapan } \\
\text { Kata }\end{array}$} & \multicolumn{4}{|c|}{$\begin{array}{c}\text { Susunan Kata } \\
\text { dalam } \\
\text { Kalimat }\end{array}$} & & \\
\hline & & 1 & 2 & 3 & 4 & 1 & 2 & 3 & 4 & 1 & 2 & 3 & 4 & & \\
\hline 1 & & & & & & & & & & & & & & & \\
\hline 2 & & & & & & & & & & & & & & & \\
\hline 3 & & & & & & & & & & & & & & & \\
\hline 4 & & & & & & & & & & & & & & & \\
\hline
\end{tabular}

b. Ketuntasan Klasikal

Jika kurang dari $85 \%$ proses pembelajaran perlu perbaikan dan tidak dianjurkan untuk melanjutkan pada pembelajaran berikutnya, sedangkan jika melebihi dari $85 \%$ dapat melanjutkan pada program pembelajaran berikutnya, dapat menggunakan rumus:

$$
\frac{\text { Jumlah siswa yang tuntas }}{\text { jumlah seluruh siswa }} \times 100 \%
$$

(Hayati, 2013)

Tabel 3. Kriteria Penilaian

\begin{tabular}{|c|c|c|}
\hline NO & Persentase $(\%)$ & Kategori \\
\hline 1 & $<70 \%$ & Rendah \\
\hline 2 & $70-79 \%$ & Cukup \\
\hline 3 & $80-89 \%$ & Tinggi \\
\hline 4 & $90-100 \%$ & Sangat Tinggi \\
\hline
\end{tabular}


2. Observasi

Tabel 4. Kriteria Lembar Observasi

\begin{tabular}{|c|c|c|}
\hline No & Pernyataan & Skor \\
\hline 1 & Ya & 1 \\
\hline 2 & Tidak & 0 \\
\hline
\end{tabular}

Nilai Rata-rata :

$$
\frac{\text { Jumlah item yang diperoleh }}{\text { jumlah maksimal }} \times 100 \%
$$

Tabel 5. Kriteria tingkat aktivitas guru dan siswa

\begin{tabular}{|c|l|c|}
\hline No & \multicolumn{1}{|c|}{ Presentase Keterlaksanaan } & Kriteria \\
\hline 1 & Nilai rata-rata $75 \%-100 \%$ & Sangat Baik \\
\hline 2 & Nilai rata-rata $50 \%-75 \%$ & Baik \\
\hline 3 & Nilai rata-rata $25 \%-50 \%$ & Cukup Baik \\
\hline 4 & Nilai rata-rata $0 \%-25 \%$ & Kurang Baik \\
\hline
\end{tabular}

(Hindun, 2015)

\section{HASIL DAN DISKUSI}

a. Keterampilan Menulis Siswa Sebelum Menggunakan Model Induktif Kata Bergambar

Pelaksanaan pembelajaran bahasa Indonesia pada pra siklus di kelas II MI Nurul Huda Kota Bandung dilaksanakan pada hari Senin tanggal 14 April. Tahap pra siklus ini dilakukan selama 70 menit. Pra siklus ini terdiri dari empat tahap yakni perencanaan, pelaksanaan/tindakan, pengamatan/observasi, dan refleksi. kemampuan menulis permulaan siswa di kelas II MI Nurul Huda Kota Bandung pada pra siklus sebesar 60 dengan persentase ketuntasan klasikal 30\% dengan kriteria rendah atau 7 orang siswa sudah memenuhi nilai KKM yang ditentukan yaitu 75 dan 16 orang siswa (70\%) masih belum memenuhi kriteria ketuntasan minimal yang telah ditentukan.

Persentase ketuntasan keterampilan menulis siswa di kelas II MI Nurul Huda Kota Bandung dapat dilihat pada grafik berikut:

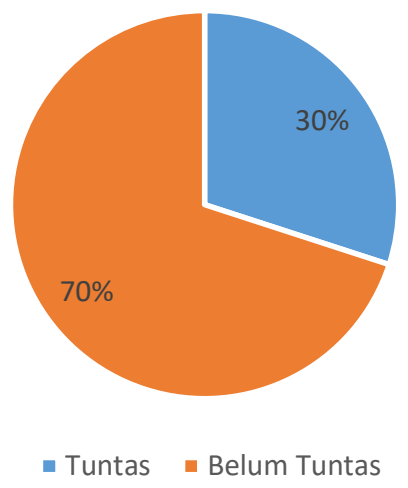

Grafik 1. Persentase Keterampilan Menulis Siswa 
b. Penerapan Model Induktif Kata Bergambar Pada Mata Pelajaran Bahasa Indonesia Tiap Siklus

1) Siklus I

Siklus I terdiri dari dua tindakan. Tindakan pertama dilaksanakan pada hari senin tagal 16 April 2018 dan tindakan kedua dilaksanakan pada hari rabu tanggal 18 Maret 2018. Siklus ini terdiri dari empat tahap yakni perencanaan/tindakan, pengamatan/observasi, dan refleksi.

Tabel 6. Lembar Observasi Aktivitas Siswa Siklus I Tindakan I

\begin{tabular}{|c|c|c|c|}
\hline \multirow{2}{*}{ No } & \multirow{2}{*}{ Aspek yang Diamati } & \multicolumn{2}{|c|}{ Kriteria } \\
\hline & & $\mathrm{Ya}$ & Tidak \\
\hline 1 & Mengidentifikasi gambar yang diperlihatkan & $\sqrt{ }$ & \\
\hline 2 & $\begin{array}{l}\text { Menandai gambar dengan merentangkan garis } \\
\text { dan memberikan kata }\end{array}$ & $\sqrt{ }$ & \\
\hline 3 & Membaca kata pada gambar tersebut & $\sqrt{ }$ & \\
\hline 4 & $\begin{array}{l}\text { Membuat/menciptakan judul untuk gambar } \\
\text { tersebut }\end{array}$ & $\sqrt{ }$ & \\
\hline 5 & $\begin{array}{l}\text { Menyusun sebuah kalimat yang berhubungan } \\
\text { dengan gambar tersebut }\end{array}$ & $\sqrt{ }$ & \\
\hline 6 & Membuat kesimpulan bersama-sama & & $\sqrt{ }$ \\
\hline 7 & Menjawab pertanyaan guru & & $\sqrt{ }$ \\
\hline 8 & Berdo'a bersama-sama & & $\sqrt{ }$ \\
\hline & Jumlah seluruh aktifitas siswa & \multicolumn{2}{|c|}{5} \\
\hline & Presentase & $62,5 \%$ & $37,5 \%$ \\
\hline
\end{tabular}

Berdasarkan tabel 6 diperoleh hasil observasi siklus I tindakan pertama dengan menggunakan model induktif kata bergambar untuk meningkatkan keterampilan menulis siswa pada mata pelajaran bahasa Indonesia materi ungkapan permintaan maaf yang telah diteliti melalui 8 point yaitu 5 point yang terlaksana dengan presentase adalah $62,5 \%$ dengan kriteria baik.

Tabel 7. Lembar Observasi Aktivitas Siswa Siklus I Tindakan 2

\begin{tabular}{|c|l|c|c|}
\hline \multirow{2}{*}{ No } & \multicolumn{1}{|c|}{ Aspek yang Diamati } & \multicolumn{2}{|c|}{ Kriteria } \\
\cline { 3 - 4 } & \multicolumn{1}{|c|}{ Ya } & Tidak \\
\hline 1 & Mengidentifikasi gambar yang diperlihatkan & $\sqrt{ }$ & \\
\hline 2 & $\begin{array}{l}\text { Menandai gambar dengan merentangkan garis } \\
\text { dan memberikan kata }\end{array}$ & $\sqrt{ }$ & \\
\hline 3 & Membaca kata pada gambar tersebut & $\sqrt{ }$ & \\
\hline 4 & $\begin{array}{l}\text { Membuat/menciptakan judul untuk gambar } \\
\text { tersebut }\end{array}$ & $\sqrt{ }$ & \\
\hline
\end{tabular}




\begin{tabular}{|c|l|c|c|}
\hline 5 & $\begin{array}{l}\text { Menyusun sebuah kalimat yang berhubungan } \\
\text { dengan gambar tersebut }\end{array}$ & $\sqrt{ }$ & $\sqrt{ }$ \\
\hline 6 & Membuat kesimpulan bersama-sama & $\sqrt{ }$ & \\
\hline 7 & Menjawab pertanyaan guru & & $\sqrt{|c|} 6$ \\
\hline 8 & Berdo'a bersama-sama & $75 \%$ & $25 \%$ \\
\hline \multirow{2}{*}{ Jumlah seluruh aktifitas siswa } & Persentase & \multicolumn{2}{|c|}{} \\
\hline
\end{tabular}

$$
\begin{aligned}
\text { Nilai Rata-rata } & =\frac{\text { Jumlah item yang diperoleh }}{\text { jumlah maksimal }} \times 100 \% \\
& =\frac{6}{8} \times 100 \%=75 \%
\end{aligned}
$$

Berdasarkan tabel 7. diperoleh hasil observasi siklus I tindakan kedua dengan menggunakan model induktif kata bergambar untuk meningkatkan keterampilan menulis siswa pada mata pelajaran bahasa Indonesia materi tentang ungkapan permintaan maaf yang telah diteliti melalui 8 point yaitu ada 6 point yang terlaksana dengan presentasenya adalah $75 \%$ dengan kriteria sangat baik.

Tabel 8. Nilai Rata-rata Aktivitas Siswa Siklus I

\begin{tabular}{|c|c|c|}
\hline No & Tindakan & Hasil Observasi \\
\hline 1 & Tindakan Pertama & $62,5 \%$ \\
\hline 2 & Tindakan kedua & $75 \%$ \\
\hline \multicolumn{2}{|c|}{ Jumlah } & 137,5 \\
\hline & Rata-rata Persentase & $68,75 \%$ \\
\hline
\end{tabular}

Kriteria ketelaksanaan observasi aktivitas siswa pada tabel 8, menunjukan angka 68,75\% masuk ke dalam kriteria baik. Presentase nilai ratarata aktivitas siswa pada siklus I dapat dilihat pada grafik sebagai berikut:

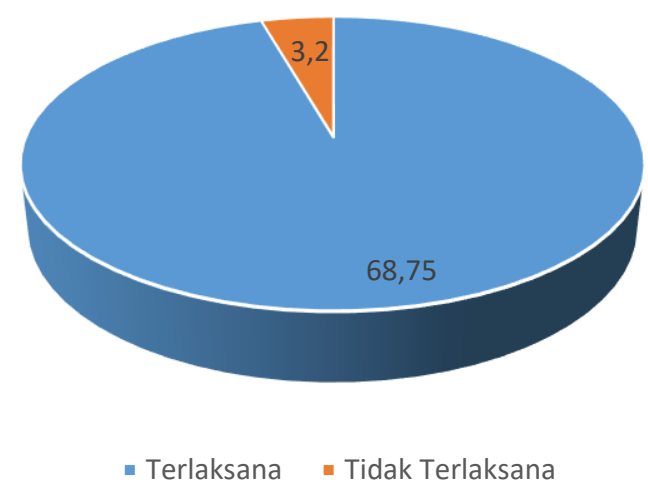

Grafik 2. Persentase Nilai Rata-Rata Aktivitas Siswa siklus I 
Tabel 9. Lembar Observasi Aktivitas Guru Siklus I Tindaka 1

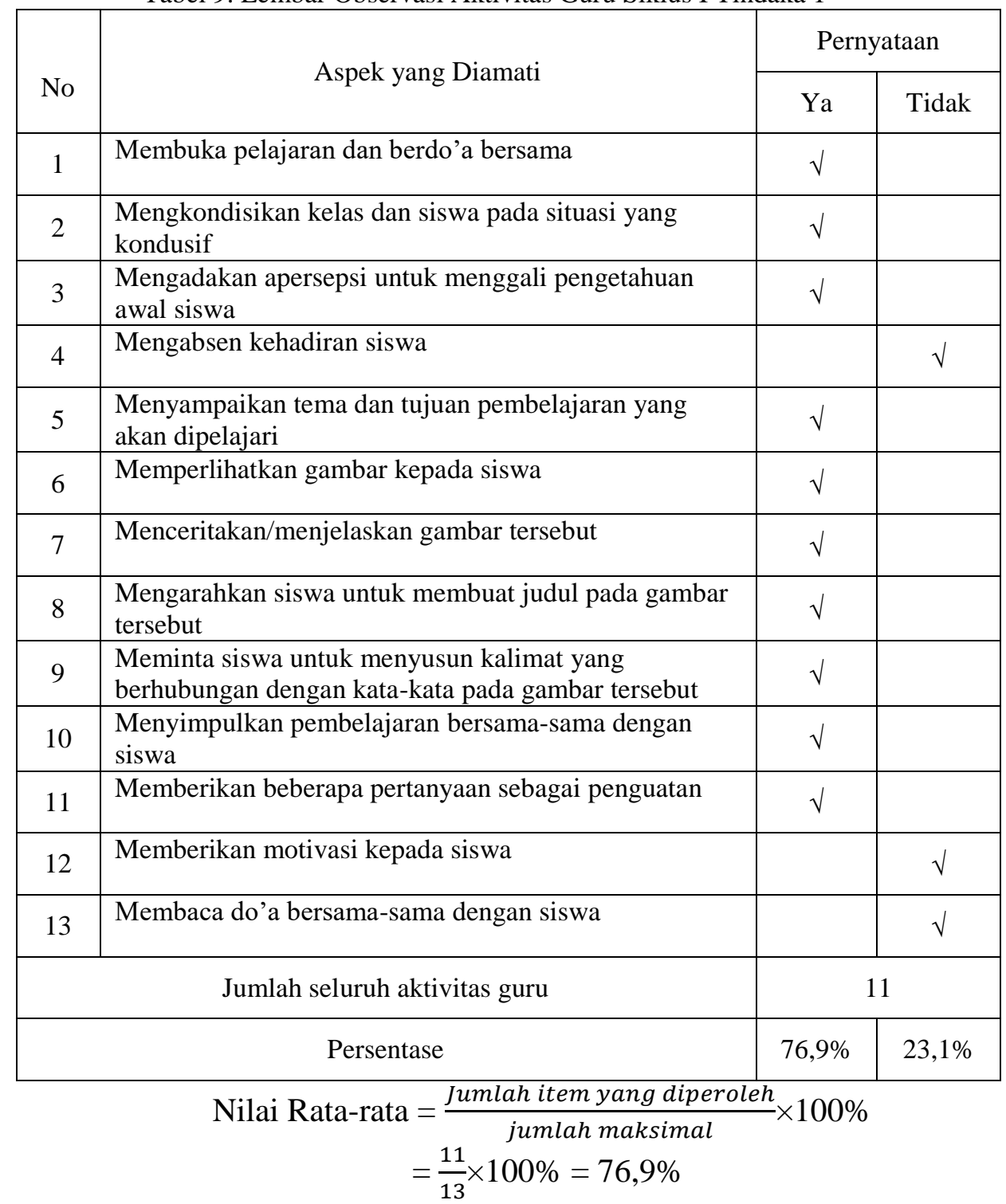

Berdasarkan tabel 9. diperoleh persentase aktivitas guru pada siklus I tindakan 1 sebesar 76,9\% dengan kriteria sangat baik. Namun, dari proses pembelajaran masih terdapat 3 poin yang belum terlaksana dengan baik untuk itu maka, harus diperbaiki pada tindakan selanjutnya. 
Tabel 10. Lembar Observasi Aktivitas Guru Siklus I Tindakan 2

\begin{tabular}{|c|c|c|c|}
\hline \multirow{2}{*}{ No } & \multirow{2}{*}{ Aspek yang Diamati } & \multicolumn{2}{|c|}{ Pernyataan } \\
\hline & & $\mathrm{Ya}$ & Tidak \\
\hline 1 & Membuka pelajaran dan berdo'a bersama & $\sqrt{ }$ & \\
\hline 2 & $\begin{array}{l}\text { Mengkondisikan kelas dan siswa pada situasi yang } \\
\text { kondusif }\end{array}$ & $\sqrt{ }$ & \\
\hline 3 & $\begin{array}{l}\text { Mengadakan appersepsi untuk menggali pengetahuan } \\
\text { awal siswa }\end{array}$ & $\sqrt{ }$ & \\
\hline 4 & Mengabsen kehadiran siswa & & $\sqrt{ }$ \\
\hline 5 & $\begin{array}{l}\text { Menyampaikan tema dan tujuan pembelajaran yang } \\
\text { akan dipelajari }\end{array}$ & $\sqrt{ }$ & \\
\hline 6 & Memperlihatkan gambar kepada siswa & $\sqrt{ }$ & \\
\hline 7 & Menceritakan/menjelaskan gambar tersebut & $\sqrt{ }$ & \\
\hline 8 & $\begin{array}{l}\text { Mengarahkan siswa untuk membuat judul pada } \\
\text { gambar tersebut }\end{array}$ & $\sqrt{ }$ & \\
\hline 9 & $\begin{array}{l}\text { Meminta siswa untuk menyusun kalimat yang } \\
\text { berhubungan dengan kata-kata pada gambar tersebut }\end{array}$ & $\sqrt{ }$ & \\
\hline 10 & $\begin{array}{l}\text { Menyimpulkan pembelajaran bersama-sama dengan } \\
\text { siswa }\end{array}$ & $\sqrt{ }$ & \\
\hline 11 & Memberikan beberapa pertanyaan sebagai penguatan & $\sqrt{ }$ & \\
\hline 12 & Memberikan motivasi kepada siswa & $\sqrt{ }$ & \\
\hline 13 & Membaca do'a bersama-sama dengan siswa & & $\sqrt{ }$ \\
\hline & Jumlah seluruh aktivitas guru & \multicolumn{2}{|c|}{12} \\
\hline \multicolumn{4}{|c|}{\begin{tabular}{c|c|c} 
Persentase & $84,61 \%$ & $\begin{array}{c}15,39 \\
\%\end{array}$ \\
\multicolumn{2}{|c|}{ Jumlah item yang diperoleh } & 1007
\end{tabular}} \\
\hline
\end{tabular}

Berdasarkan tabel 10. diperoleh persentase aktivitas guru pada siklus I tindakan 1 sebesar $84,61 \%$ dengan kriteria sangat baik. Namun, dari proses pembelajaran masih terdapat 2 poin yang belum terlaksana dengan baik untuk itu maka, harus diperbaiki pada tindakan selanjutnya.

Tabel 11. Nilai Rata-rata Aktivitas Guru Siklus I

\begin{tabular}{|c|c|c|}
\hline No & Tindakan & Hasil Observasi \\
\hline 1 & Tindakan Pertama & $76,9 \%$ \\
\hline 2 & Tindakan kedua & $84,61 \%$ \\
\hline \multicolumn{2}{|c|}{ Jumlah } & 161,5 \\
\hline \multicolumn{2}{|c|}{ Rata-rata Presentase } & $80,75 \%$ \\
\hline
\end{tabular}


Persentase nilai rata-rata aktivitas guru pada siklus I dapat dilihat pada garfik berikut:

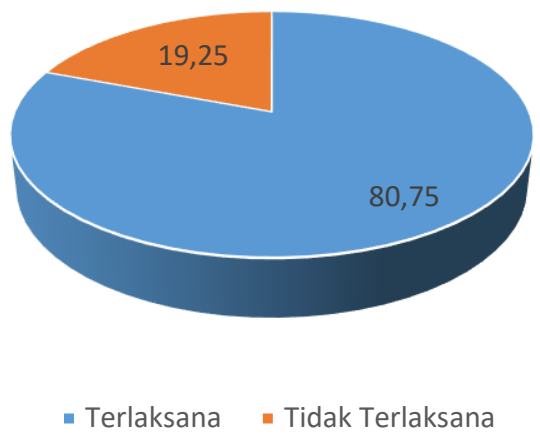

Grafik 3. Persentase nilai Rata-rata Aktivitas Guru Siklus I

Aktivitas guru pada siklus I tindakan 1 dan tindakan 2 berdasarkan pemaparan di atas, mengalami peningkatan pada setiap tindakannya yaitu pada tindakan 1 diperoleh aktivitas guru sebesar 76,9\% dengan kriteria sangat baik dan pada tindakan 2 diperoleh aktivitas guru sebesar 84,61\% dengan kriteria sangat baik

\section{2) Siklus II}

Tabel 12. Lembar Observasi Aktivitas Siswa Siklus II Tindakan 1

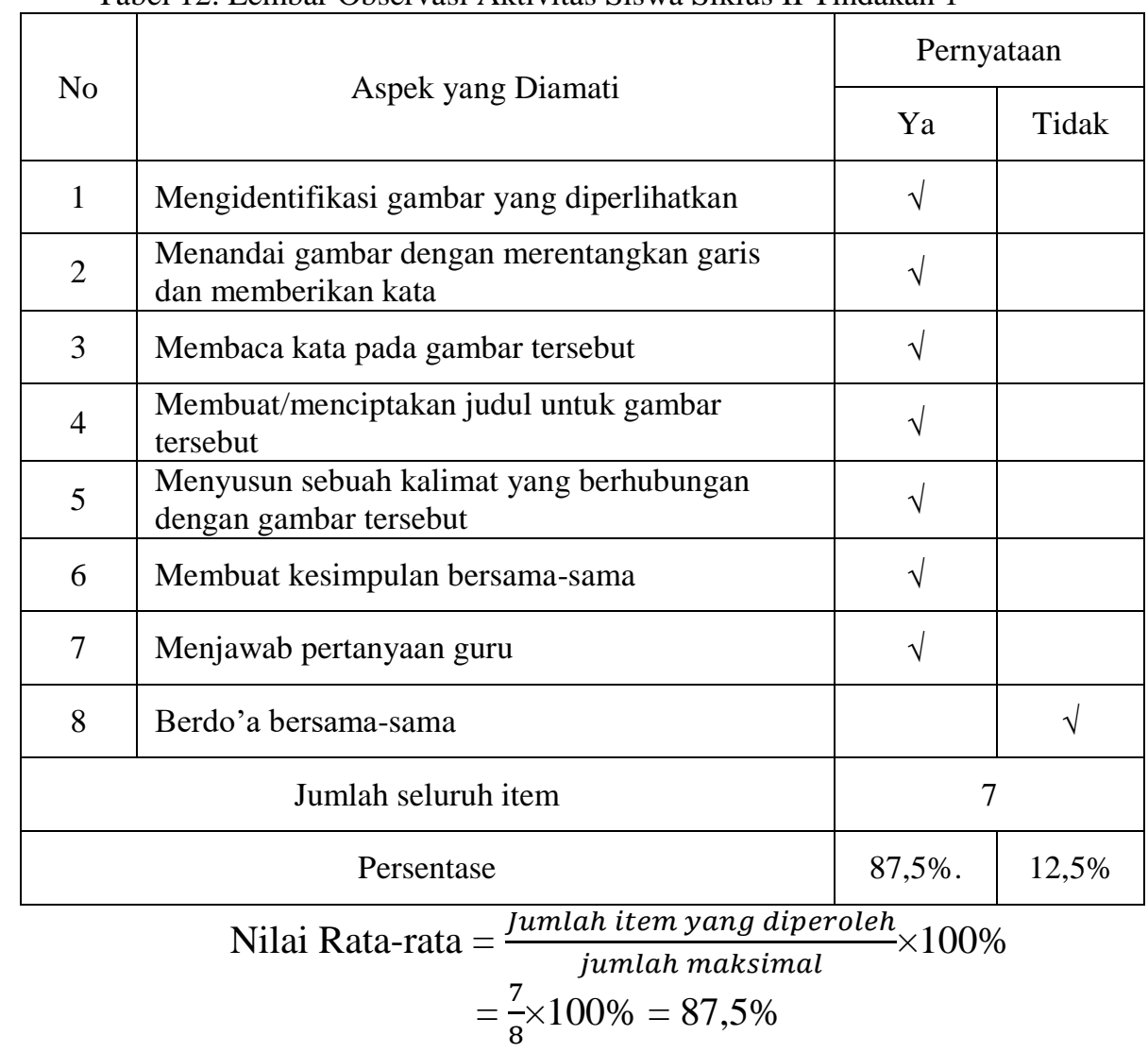


Berdasarkan tabel 12. diperoleh persentase aktivitas siswa pada siklus II tindakan 1 sebesar $87,5 \%$ dengan kriteria sangat baik dengan 7 poin yang sudah terlaksana dengan baik dan 1 item belum terlaksana dengan baik.

Tabel 13. Lembar Observasi Aktivitas Siswa Siklus II Tindakan 2

\begin{tabular}{|c|c|c|c|}
\hline \multirow{2}{*}{ No } & \multirow{2}{*}{ Aspek yang Diamati } & \multicolumn{2}{|c|}{ Pernyataan } \\
\hline & & $\mathrm{Ya}$ & Tidak \\
\hline 1 & Mengidentifikasi gambar yang diperlihatkan & $\sqrt{ }$ & \\
\hline 2 & $\begin{array}{l}\text { Menandai gambar dengan merentangkan garis } \\
\text { dan memberikan kata }\end{array}$ & $\sqrt{ }$ & \\
\hline 3 & Membaca kata pada gambar tersebut & $\sqrt{ }$ & \\
\hline 4 & $\begin{array}{l}\text { Membuat/menciptakan judul untuk gambar } \\
\text { tersebut }\end{array}$ & $\sqrt{ }$ & \\
\hline 5 & $\begin{array}{l}\text { Menyusun sebuah kalimat yang berhubungan } \\
\text { dengan gambar tersebut }\end{array}$ & $\sqrt{ }$ & \\
\hline 6 & Membuat kesimpulan bersama-sama & $\sqrt{ }$ & \\
\hline 7 & Menjawab pertanyaan guru & $\sqrt{ }$ & \\
\hline 8 & Berdo'a bersama-sama & $\sqrt{ }$ & \\
\hline & Jumlah seluruh item & \multicolumn{2}{|c|}{8} \\
\hline & Persentase & $100 \%$ & - \\
\hline
\end{tabular}

Nilai Rata-rata $=\frac{\text { Jumlah item yang diperoleh }}{\text { jumlah maksimal }} \times 100 \%$

$$
=\frac{8}{8} \times 100 \%=100 \%
$$

Berdasarkan tabel 13. diperoleh persentase aktivitas siswa pada siklus II tindakan 1 sebesar $100 \%$ dengan kriteria sangat baik dengan 8 poin yang sudah terlaksana dengan baik.

Tabel 14. Nilai Rata-rata Aktivitas Siswa Siklus II

\begin{tabular}{|c|c|c|}
\hline No & Tindakan & Hasil Observasi \\
\hline 1 & Tindakan Pertama & $87,5 \%$ \\
\hline 2 & Tindakan kedua & $100 \%$ \\
\hline \multicolumn{2}{|c|}{ Jumlah } & 187,5 \\
\hline \multicolumn{2}{|c|}{ Rata-rata Presentase } & $93,75 \%$ \\
\hline
\end{tabular}

Persentase nilai rata-rata aktivitas siswa pada siklus II dapat dilihat pada grafik berikut: 


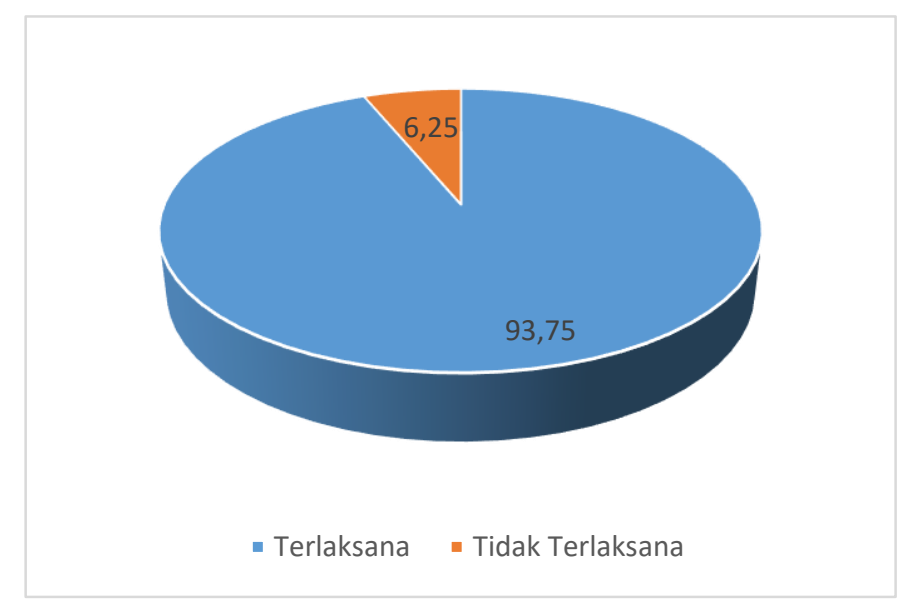

Grafik 10. Persentase nilai rata-rata aktivitas siswa siklus II

Aktivitas siswa pada siklus II mengalami peningkatan pada setiap tindakannya. Pada siklus II tindakan 1diperoleh hasil sebesar $87,5 \%$ dengan kriteria sangat baik. Pada siklus II diperoleh aktivitas siswa sebesar 100\% dengan kriteria sangat baik. Dari hasil tersebut diperoleh nilai rata-rata dengan persentase sebesar $93,75 \%$ dengan kriteria sangat baik

Tabel 15. Nilai rata-rata aktivitas guru siklus II

\begin{tabular}{|c|c|c|}
\hline No & Tindakan & Hasil Observasi \\
\hline 1 & Tindakan Pertama & $92,3 \%$ \\
\hline 2 & Tindakan kedua & $100 \%$ \\
\hline \multicolumn{2}{|c|}{ Jumlah } & 192,3 \\
\hline \multicolumn{2}{|c|}{ Rata-rata Presentase } & $96,15 \%$ \\
\hline
\end{tabular}

Persentase nilai rata-rata aktivitas guru pada siklus II dapat dilihat pada grafik berikut:

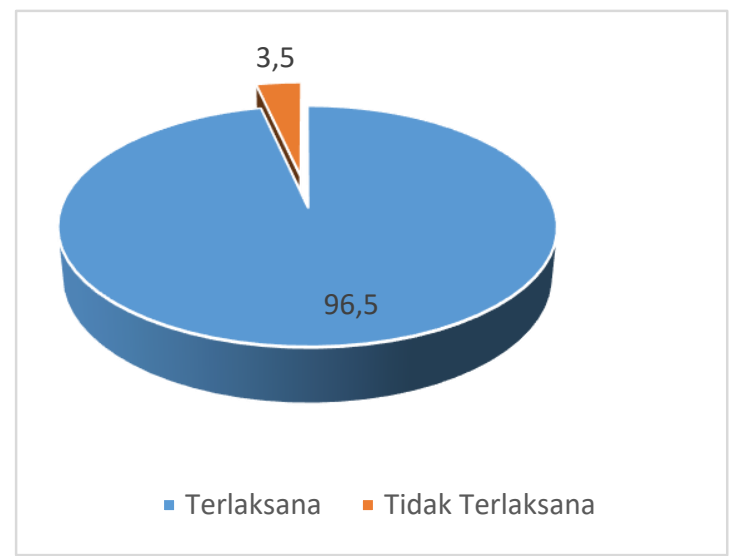

Grafik 11. Persentase Nilai rata-rata Aktivitas Guru Siklus II

Berdasarkan pemaparan di atas, terjadi peningkatan aktivitas siswa mapun aktivitas guru pada setiap tindakan dalam setiap siklus. Peningkatan aktivitas siswa dan aktivitas guur dapat dilhat pada grafik berikut: 


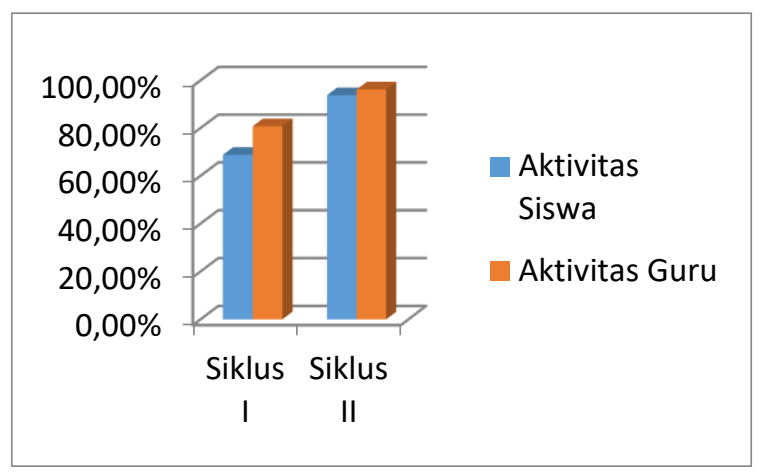

Grafik 12. Persentase Peningkatan Aktivitas Siswa dan Guru

c. Keterampilan Menulis Siswa Susudah Menggunakan Model Induktif Kata Bergambar

Tabel 16. Perolehan nilai berdasarkan KKM pada siklus I

\begin{tabular}{|c|c|c|}
\hline No & Persentase keterlaksanaan & Banyak siswa \\
\hline 1 & Siswa yang $\geq 75$ & 18 orang \\
\hline 2 & Siswa yang $\leq 75$ & 5 orang \\
\hline
\end{tabular}

Unjuk kerja individu siswa yang mendapatkan nilai lebih dari KKM yaitu sebanyak 18 orang dan yang mendapatkan nilai kurang dari KKM yaitu sebanyak 5 orang. Maka secara klasikal dapat diperoleh rata-ratanya yaitu dengan menggunakan rumus

$$
\begin{aligned}
\text { Nilai Rata-rata } & =\frac{\text { jumlah siswa yang } \geq 75}{\text { jumlah seluruh siswa }} \times 100 \\
& =\frac{18}{23} \times 100 \\
= & 78,26 \%
\end{aligned}
$$

Angka 78,26\% apabila melihat kepada kriteria penilaian termasuk ke dalam kategori "Baik". Berdasarkan rekapitulasi siklus I di atas, maka dapat diketahui peningkatan keterampilan menulis siswa pada pembelajaran bahasa Indonesia materi ungkapan permintaan maaf. Hal ini bisa dilihat dari presentase yang diperoleh yaitu sebesar 78,26\%.

Tabel 17. Nilai Ketuntasan Keterampilan Menulis Siswa Siklus II

\begin{tabular}{|c|c|c|}
\hline No & Persentase keterlaksanaan & Banyak siswa \\
\hline 1 & Siswa yang $\geq 75$ & 23 orang \\
\hline 2 & Siswa yang $\leq 75$ & - orang \\
\hline
\end{tabular}

Unjuk kerja individu siswa yang mendapatkan nilai lebih dari KKM yaitu sebanyak 23 orang dan yang mendapatkan nilai kurang dari KKM yaitu tidak ada, maka secara klasikal dapat diperoleh rata-rata yaitu dengan menggunakan rumus :

$$
\begin{aligned}
\text { Nilai Rata-rata } & =\frac{\text { jumlah siswa yang } \geq 75}{\text { jumlah seluruh siswa }} \times 100 \\
& =\frac{23}{23} \times 100 \\
& =100 \%
\end{aligned}
$$

Angka $100 \%$ apabila melihat kepada kriteria penilaian termasuk ke dalam kategori "Sangat Baik"berdasarkan rekapitulasi siklus II di atas, maka dapat diketahui peningkatan keterampilan menulis siswa pada pembelajaran bahasa 
Indonesia materi permintaan maaf. Hal ini bisa dilihat dari presentase yang diperoleh yaitu sebesar $100 \%$

Peningkatan keterampilan menulis siswa pada setiap siklus dapat dilihat pada grafik berikut:

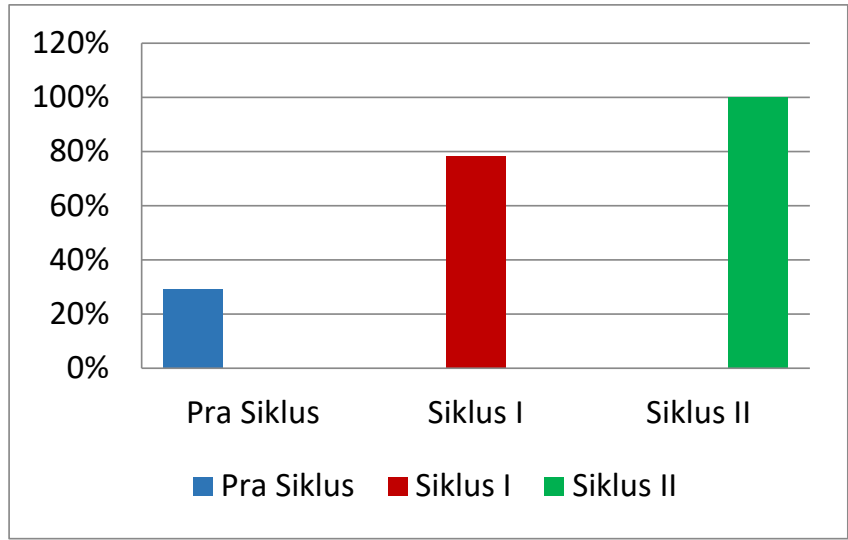

Grafik 13. Peningkatan Keterampilan Menulis Siswa Pada Setiap Siklus

Peningkatan keterampilan menulis siswa dengan menggunakan model induktif kata bergambar untuk meningkatkan keterampilan menulis siswa pada mata pelajaran bahasa Indonesia materi ungkapan permintaan maaf mengalami peningkatan setiap siklusnya. Peningkatan tersebut meliputi pra siklus $29 \%$ (kurang), siklus I 78,26\% (Baik), dan siklus II 100\% (sangat aktif).

\section{KESIMPULAN}

Berdasarkan penelitian yang diperoleh dapat disimpulkan sebagai berikut: 1) keterampilan menulis siswa sebelum menggunakan model induktif kata bergambar masih rendah yaitu dengan nilai rata-rata 60 dengan persentase ketuntasan belajar mencapai 30\% dengan kriteria tidak tuntas. 2) penerapan model induktif kata bergabar mengalami peningkatan pada setiap siklusnya yaitu pada siklus I nilai rata-rata aktivitas guru sebesar $80,75 \%$ dengan kriteria sangat baik dan aktivitas siswa sebesar 68,75\% dengan kriteria baik. Pada siklus II aktivitas guru diperoleh nilai rata-rata sebesar 96,15\% dengan kriteria sangat baik dan aktivitas siswa sebesar 93,75 dengan kriteria sangat baik. 3) keterampilan menulis siswa sesudah menggunakan model induktif kata bergambar mengalami peningkatan pada setiap siklusnya. Pada siklus I diperoleh nilai rata-rata keterampilan menulis siswa sebesar 74,5 dengan persentase ketuntasan belajar sebesar 78\% dan pada siklus II diperoleh nilai rata-rata keterampilan menulis siswa sebesar 81,6 dengan persentase sebesar $100 \%$. Berdasarkan data tersebut dapat disimpulkan bahwa pembelajaran bahasa Indonesia dengan menggunakan model induktif kata bergambar dpat meningkatan keterampilan menulis siswa di kelas II MI Nurul Huda Kota Bandung.

\section{DAFTAR PUSTAKA}

Anwar. (2017). Pembelajaran Qur'an Hadis di Madrasah Ibtidaiyah. Bandung. Hayati, T. (2013). Evaluasi Pembelajaran. Bandung: CV. Insan Mandiri.

Hindun, Siti. (2015). Penerapan Model Coopeartive Learning Tipe Number Heads Together (NHT) Untuk Meningkatkan Hasil Belajar Kognitif Siswa Pada Mata Pelajaran Sejarah Kebudayaan Islam Pokok Bahasan Mengenal Peristiwa Kerasulan Nabi Muhammad SAW Pada Kelas III MI Yapinur Limbangan-Garut. Unpublished. UIN Bandung 
Jamaludin. (2015). Belajar dan Pembelajaran. Bandung .PT. Remaja Rosda karya

Saefuddin, A. dan Berdiati, I. Pembelajaran Bahasa Indonesia di MI/SD. Bandung:Tidak diterbitkan

Sobry. (2018). Landasan pendidikan Bandung prospek Bandung

Susanto. (2013). Teori belajar dan pembelajaran di sekolah dasar. Jakarta : Kencana Prenada Media Group. 